Postharvest quality and sensitivity to anthracnose disease of Carica papaya L. 'Red Lady' affected by

Papaya ring spot virus

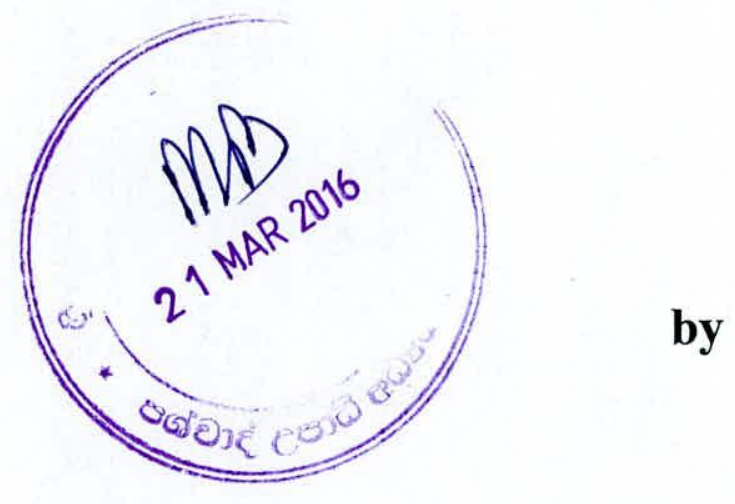

Peella Kankanamage Chamika Buddhinie

Thesis submitted to the University of Sri Jayewardenepura for the Degree of Master of Philosophy in Botany 
I / we certify that by the candidate has incorporated all corrections, additions and amendments recommended by the examiners.

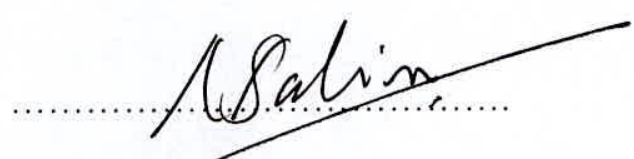

Prof (Mrs). N. Salim

(Principal Supervisor)

Date: $14^{\text {th }}$. Manch 20.16

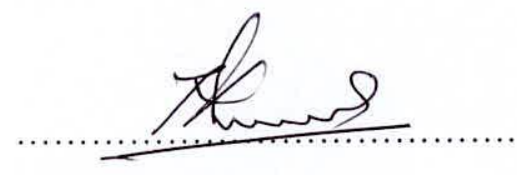

Dr. K. H. Sarananda

(External Supervisor)

Date: $\ldots 18 / 3 / 20 / 6$ 


\section{DECLARATION}

The work described in this thesis was carried out by me under the supervision of Prof

(Mrs). N. Salim and Dr. K.H. Sarananda and a report on this has not been submitted in whole or in part to any University or any other Degree/Diploma.

Plolum Rundernie.

P. K. C. Buddhinie

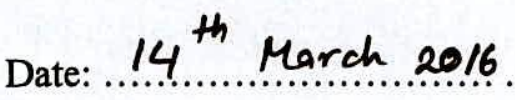


We certify that the above statement made by the candidate is true and that this thesis is suitable for submission to the University for the purpose of evaluation.

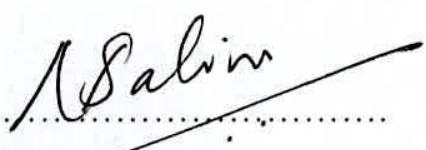

Prof (ATS). N. Salim

(Principal Supervisor)

Date: ..1.4...Manch.2.016

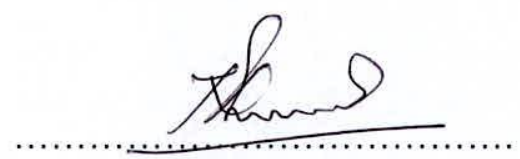

Dr. K. H. Sarananda

(External Supervisor)

Date: $. .18 / 3 / 2016$ 


\section{Table of Contents}

Page number

Table of Contents

List of Tables

List of Figures

IX

List of Plates

XIII

Acknowledgement

XV

ABSTRACT

XVIII

1. INTRODUCTION

1.1 Papaya (Carica papaya L.)

1.2 Papaya Ringspot virus disease

3

$1.3 \quad$ Postharvest diseases

$1.4 \quad$ Scope of the study

1.5 Specific objectives

2. LITERATURE REVIEW 
$2.1 \quad$ Carica papaya L.

$2.2 \quad$ Papaya Varieties $\quad 8$

2.2.1 Papaya varieties found in Sri Lanka 10

2.3 Harvesting and postharvest handling of papaya 11

$2.4 \quad$ Pests and diseases of papaya 12

2.4.1 Fungal, Bacterial and Phytoplasma diseases 13

2.4.2 Viral diseases 14

$\begin{array}{lll}\text { 2.4.2.1 Papaya ringspot virus disease } & 14\end{array}$

2.4.2.2 Biology and epidemiology of PRSV 15

2.4.2.3 Management of PRSV disease 19

2.4.3 Postharvest diseases of papaya 22

2.4.3.1 Anthracnose and Chocolate spot 22

2.4.3.2 Control of postharvest diseases 26

2.5 Nutritional value of Papaya 28

$\begin{array}{lll}2.5 .1 & \text { Carbohydrates } & 28\end{array}$

2.5.2 Protein and lipid 28

$\begin{array}{llr}2.5 .3 & \text { Minerals } & 29\end{array}$

2.5.4 Carotenoids 30

$\begin{array}{lll}2.5 .5 & \text { Ascorbic acid } & 31\end{array}$

2.6 Physico-chemical parameters of papaya 32

$\begin{array}{lll}2.6 .1 & \text { Titratable acidity } & 32\end{array}$

2.6.2 Fruit firmness 32 
2.7 Organoleptic properties of papaya

3. MATERIALS AND METHODS

3.1 Sample Collection 36

3.1.1 Field samples $\quad 36$

3.1.2 Market samples $\quad 36$

$\begin{array}{lll}3.2 & \text { PRSV disease detection } & 38\end{array}$

$\begin{array}{lll}\text { 3.2.1 PRSV detection in field samples } & 38\end{array}$

3.2.2 PRSV detection in market samples 39

3.3 Categorization of plants according to ELISA values 40

3.4 Effect of harvesting stage and degree of PRSV disease on post harvest quality of Red Lady papaya $\quad 42$

3.4.1 Harvesting stage $\quad 42$

$\begin{array}{lll}3.4 .2 & \text { Total soluble solids (TSS) } & 43\end{array}$

$\begin{array}{lll}3.4 .3 & \mathrm{pH} & 43\end{array}$

$\begin{array}{lll}3.4 .4 & \text { Titratable acidity (TA) } & 43\end{array}$

3.4.5 Fruit flesh firmness $\quad 44$

$\begin{array}{lll}\text { 3.4.6 Fruit flesh colour } & 44\end{array}$

3.5 Determination of nutritional value of PRSV affected Red Lady papaya of $\begin{array}{ll}\text { different disease levels } & 45\end{array}$

$\begin{array}{lll}\text { 3.5.1 Moisture content } & 45\end{array}$ 
3.5.3 Total crude fat content

3.5.4 Ash content

3.5.5 Total crude protein content

3.5.6 Free amino acid contents

3.5.7 Minerals

3.5.8 Vitamin C content

3.5.9 Lycopene and $\beta$ carotene content

3.6 Sensory evaluation

3.7 Sensitivity of PRSV affected Red Lady papaya to anthracnose disease

3.7.1 Isolation of Colletotrichum sp. from anthracnose lesions on Red Lady papaya

3.7.2 Natural development of anthracnose disease on Red Lady papaya fruits infected with PRSV

3.7.3 Anthracnose disease development of artificially inoculated fruits

4. RESULTS

4.2 Effect of stage of maturity at harvest and degree of disease on post harvest quality of PRSV affected Red Lady papaya

4.2.1 Interaction between stage of maturity at harvest and disease severity on post harvest quality parameters 
4.2.2 Effect of PRSV disease severity on post harvest parameters of Red Lady

papaya fruits

4.2.2.1 Effect of PRSV disease severity on TSS, TA, $\mathrm{pH}$ and fruit firmness of Red Lady papaya fruits

4.2.2.2 Effect of disease severity on flesh colour parameters of PRSV affected Red Lady papaya fruits

4.2.3 Effect of stages of maturity at harvest on post harvest parameters of PRSV infected Red Lady papaya fruits

4.2.3.1 Effect of stages of maturity at harvest on TSS, TA, $\mathrm{pH}$ and fruit firmness of field samples of PRSV infected Red Lady papaya fruits

4.2.3.2 Effect of stage of maturity at harvest on flesh colour parameters of PRSV infected Red Lady papaya field samples

4.3 Effect of PRSV infection level on nutritional parameters of Red Lady papaya 80

4.3.1 Effect of PRSV infection on percentage moisture content of Red Lady papaya

4.3.2 Effect of PRSV infection on percentage ash content 82

4.3.3 Effect of PRSV infection on percentage crude fat content 84

4.3.4 Effect of PRSV infection on percentage crude protein content 86

4.3.5 Effect of PRSV infection on free amino acid content $\quad 88$

4.3.6 Effect of PRSV infection on ascorbic acid content 95

4.3.7 Effect of PRSV infection on carotenoid content 97

4.3.8 Effect of PRSV infection on mineral contents of Red Lady papaya 102

4.4 Effect of PRSV infection on organoleptic properties of Red Lady papaya 
4.4.1 Effect of PRSV infection on odour, flavour and overall acceptability

4.5 Effect of PRSV infection on postharvest infection by Colletotrichum sp. in Red Lady papaya

4.5.1 Effect of PRSV infection on development of anthracnose lesion

4.5.2 Effect of PRSV on anthracnose lesion development in fruits artificially inoculated with Colletotrichum sp.

5. DISCUSSION

6. CONCLUSIONS

List of References

Appendices 


\section{List of tables}

Page number

Table 1: Interaction between different stages of maturity at harvest and PRSV disease severity for different post harvest parameters

Table 2: Postharvest parameters; TSS, TA, $\mathrm{pH}$, fruit firmness of fruits collected from plants with mild and severe infections of PRSV

Table 3: Flesh colour parameters $\left(\mathrm{L}^{*}, \mathrm{a}^{*}, \mathrm{~b}^{*}\right.$ and hue) of fruits from mild and severe infections of PRSV

Table 4: TSS, TA, pH and fruit firmness of Red Lady papaya fruits harvested at different stages of maturities

Table 5: Flesh colour parameters (L*, $a^{*}, b^{*}$ and hue) of PRSV infected Red Lady papaya fruits harvested at different stages of maturities irrespective of the disease severity

Table 6: Percentage moisture and ash contents of Red Lady papaya field samples

Table 7: Percentage moisture and ash contents of Red Lady papaya market samples

Table 8: Crude fat and protein contents of Red Lady papaya field samples

Table 9: Crude fat and protein contents of Red Lady papaya market samples

Table 10: Free amino acid contents in fruits of Red Lady papaya field samples

Table 11: Free amino acid contents in fruits of Red Lady papaya market samples

Table 12: Ascorbic acid content of Red Lady papaya field samples

Table 13: Ascorbic acid contentof Red Lady papaya market samples

Table 14: Lycopene and $\beta$-carotene contents of Red Lady papaya field samples 
Table 15: Lycopene and $\beta$-carotene contents of Red Lady papaya market samples

Table 16: Mineral contents of Red Lady papaya field samples

Table 17: Mineral contents of Red Lady papaya market samples

Table 18: Median values of organoleptic properties of Red Lady papaya field samples

Table 19: Median values of organoleptic properties of Red Lady papaya market samples

Table 20: Anthracnose disease development on PRSV infected Red Lady papaya fruits collected from field with different infection levels

Table 21: Anthracnose disease development on Red Lady papaya market samples with and without PRSV symptoms 


\section{List of figures}

Page number

Figure 1: The interaction plot between different stages of maturity at harvest and degree of disease for the $\mathrm{L}^{*}$ parameter of PRSV affected Red Lady fruit flesh colour

Figure 2: The interaction plot between different stages of maturity at harvest and degree of disease for the $b^{*}$ parameter of PRSV affected Red Lady fruit flesh colour

Figure 3: The boxplot of TSS values against PRSV infection levels of Red Lady papaya fruits

Figure 4: The boxplot of colour component L* against PRSV infection levels of Red Lady papaya fruit flesh colour

Figure 5: The boxplot of TSS in fruits harvested at different stages of maturity of PRSV infected Red Lady papaya fruits irrespective of the disease severity

Figure 6: The boxplot of fruit firmness against different stages of maturity at harvest of PRSV infected Red Lady papaya fruits irrespective of the disease severity

Figure 7: The boxplot of TA against different stages of maturity at harvest of PRSV infected Red Lady papaya fruits irrespective of the disease severity

Figure 8: The boxplot of $\mathrm{pH}$ against different stages of maturity at harvest of PRSV infected Red Lady papaya fruits irrespective of the disease severity 
Figure 9: The boxplot of $\mathrm{L}^{*}$ against different stages of maturity at harvest of PRSV infected Red Lady papaya fruit flesh colour irrespective of the disease severity

Figure 10: The boxplot of a* against different stages of maturity at harvest of PRSV infected Red Lady papaya fruit flesh colour irrespective of the disease severity

Figure 11: The boxplot of $b^{*}$ against different stages of maturity at harvest of PRSV infected Red Lady papaya fruit flesh colour irrespective of the disease severity

Figure 12: The boxplot of hue value against different stages of maturity at harvest of PRSV infected Red Lady papaya fruit flesh colour irrespective of the disease severity

Figure 13: The boxplot of moisture content of Red Lady papaya fruits against different PRSV infection levels of field samples (MI and SI) and market samples with and without PRSV symptoms

Figure 14: The boxplot of ash content of Red Lady papaya fruits against different PRSV infection levels of field samples (MI and SI) and market samples with and without PRSV symptoms

Figure 15: The boxplot of crude fat content of Red Lady papaya fruits against different PRSV infection levels of field samples (MI and SI) and market samples with and without PRSV symptoms

Figure 16: The boxplot of protein content of Red Lady papaya fruits against different PRSV infection levels of field samples (MI and SI) and market samples with and without PRSV symptoms 
Figure 17: The boxplot of total amino acid content of Red Lady papaya fruits against different PRSV infection levels of field samples (MI and SI) and market samples with and without PRSV symptoms

Figure 18: The boxplot of amino acid contents of Red Lady papaya fruits against different PRSV infection levels of field samples

Figure 19: The boxplot of amino acid contents of Red Lady papaya fruits against market samples with and without PRSV disease symptoms

Figure 20: The boxplot of ascorbic acid content of Red Lady papaya fruits against different PRSV infection levels of field samples (MI and SI) and market samples with and without PRSV symptoms

Figure 21: The boxplot of Lycopene content of Red Lady papaya fruits against different PRSV infection levels of field samples (MI and SI) and market samples with and without PRSV symptoms

Figure 22: The boxplot of $\beta$-carotene contents of Red Lady papaya fruits against different PRSV infection levels of field samples (MI and SI) and market samples with and without PRSV symptoms

Figure 23: The boxplot of $\mathrm{Na}$ content of Red Lady papaya fruits against different PRSV infection levels of field samples (MI and SI) and market samples with and without PRSV symptoms

Figure 24: The boxplot of Ca content of Red Lady papaya fruits against different PRSV infection levels of field samples (MI and SI) and market samples with and without PRSV symptoms 
Figure 25: The boxplot of organoleptic property - flavour of Red Lady papaya fruits against different PRSV infection levels of field samples (MI and SI) and market samples with and without PRSV symptoms

Figure 26: The boxplot of organoleptic property - odour of Red Lady papaya fruits against different PRSV infection levels of field samples (MI and SI) and market samples with and without PRSV symptoms

Figure 27: The boxplot of organoleptic property - overall acceptability of Red Lady papaya fruits against different PRSV infection levels of field samples (MI and SI) and market samples with and without PRSV symptoms

Figure 28: The boxplot of percentage anthracnose lesion development of uninoculated Red Lady papaya fruits against different PRSV infection levels of field samples (MI and SI) and market samples with and without PRSV symptoms

Figure 29: The boxplot of percentage anthracnose lesion development of artificially Colletotrichum sp. inoculated Red Lady papaya fruits against different PRSV infection levels of field samples (MI and SI) and market samples with and without PRSV symptoms 


\section{List of plates}

Page number

Plate 1: Electron micrograph of papaya ringspot virus particles

Plate 2: Leaf mosaic and shoestring appearance of PRSV infected papaya leaves

Plate 3: Characteristic ringspot symptoms of PRSV infected papaya fruits

Plate 4: Typical anthracnose lesion on papaya fruit skin

Plate 5: Chocolate spot symptoms on papaya fruit skin

Plate 6: Attributes of $\mathrm{L}^{*}, \mathrm{a}^{*}, \mathrm{~b}^{*}$ colour space

Plate 7: Hue value scale for $\mathrm{L}^{*} \mathrm{a} * \mathrm{~b} *$ colour space

Plate 8: Red Lady market samples without PRSV disease symptoms

Plate 9: Red Lady market samples with PRSV symptoms

Plate 10: Micro titre ELISA plate after adding PNP substrate

Plate 11: Red Lady papaya fruits harvested at different stages of maturity; 1. Colour break stage, 2. $10 \%$ yellow, 3. $20 \%$ yellow, 4 . $30 \%$ yellow, 5 . $40 \%$ yellow

Plate 12: Papaya fruit cubes prepared for sensory evaluation

Plate 13: Colletotrichum sp. grown on PDA plate

Plate 14: Colletotrichum sp. spores under high power $(\times 40)$ resolution of light microscope

Plate 15: Red Lady papaya fruits incubated in glass chambers to develop natural anthracnose lesions

Plate 16: Anthracnose lesion development on anun-inoculated Red Lady papaya fruit collected from mildly PRSV infected plant 
Plate 17: Anthracnose lesion development on a Red Lady papaya fruit collected from mildly infected plant inoculated with spores of Colletotrichum sp at $2 \times 10^{5}$ spores $/ \mathrm{ml}$ concentration. 


\section{Acknowledgement}

I am deeply indebted to my principal supervisor, Prof (Mrs) N. Salim of Department of Botany, University of Sri Jayewardenepura whose stimulating motivation, enormous support and invaluable ideas helped me in completing this research. It is a great honor to work under her supervision and without her guidance and persistent support this thesis would not have been possible. I would like to express my sincere gratitude and heartfelt appreciationto my external supervisor Dr. K. H. Sarananda, Head, Food Research Unit, Gannoruwa for guiding me and providing invaluable advices throughout the research. I am greatly indebted to him for his patients and immense support rendered.

My heartfelt gratitude goes to Mr. Waruna Madawanaarachchi, CEO of CIC Agribusiness (Pvt) Ltd, General Manager Mr. Priyanga Dematawa, Assistant Manager Mr. Sumith Attanayake, Mr. Hemantha, and Mr. Waruna of CIC farm, Pelwehera for allowing me to collect samples from their papaya fields without any hesitation.

I am grateful to Dr. N. Punyasiri, Nature's Secrets (Pvt) Ltd, Dr. U.G. Chandrika, Department of Biochemistry, University of Sri Jayewardenepura, Dr. V. Basnayake of Plant Virus indexing center, Homagama, Dr. M. Iqbal and Dr. M. S. Vithanage of Institute of Fundamental Studies, Kandy, Mr. D.P.C. Swarnasiri, and Miss Suneka of Institute of Postharvest Technology, Anuradhapura for their invaluable cooperation provided to me to fulfill my research objectives.

I sincerely acknowledge the support given by the academic and non academic staff of Department of Botany, University of Sri Jayewardenepura throughout the study. 
Generosity of the academic and supporting staff of the Department of Food Science and Technology and Department of Biochemistry is highly appreciated. Without their help, some of the experiments in the study could not have been completed.

Special thank goes to late Mr. G.R.N. Kandambi of Department of Botany, USJP for his enormous support and valuable advices given.

The financial assistant provided by the University Grant, USJP (ASP/PR/06/2010/13) is highly acknowledged.

I am eternally grateful to my dear friend Mrs. Wajira Nandanee of Department of Botany, USJP for her immense support, encouraging words and true affection which was helped me a lot in my difficult times.

I express my sincere thanks to my parents and childhood friends Nuwani, Thanuja, Asanga and Padmanath who has gave me confidence and motivated me in so many ways. Their love and dedication bestowed to me throughout my life is priceless.

I would like to express my deepest gratitude to my loving husband, Najith Wijerathna for his invaluable support and encouragement. Through his love, patience, enthusiasm and unwavering belief in me, I have been able to complete my research work.

Finally my biggest thank goes to my little daughter, Tarinya Monadee, who has patiently endured many long hours alone while I worked on my research. Her unconditional love always inspires me to meet success in my life. 
This thesis is dedicated to my lovely, little daughter;

Tarinya Monadee Wijerathna 


\title{
Postharvest quality and sensitivity to anthracnose disease of Carica papaya L. 'Red Lady' affected by Papaya ring spot virus \\ P. K. C. Buddhinie
}

\begin{abstract}
Papaya (Carica papaya L.) Red Lady variety has been identified as a papaya ring spot virus (PRSV) - tolerant variety. However, Red Lady papaya fruits with abundant ring spot symptoms on skins are commonly seen in local market since last few years.

Therefore, an investigation was carried out to determine any effects of this virus on post harvest and nutritional parameters of papaya Red Lady fruits. A sensory evaluation also was carried out to determine the effect of PRSV on organoleptic properties of fruits. The investigation was further extended to find out the effect of PRSV on anthracnose disease development of papaya fruits.
\end{abstract}

Since the initial screening carried out at commercial 'Red Lady' plantations showed plants with no external virus symptoms also carry PRSV, they were categorized into severe and mild disease levels based on the results of double antibody sandwich enzyme linked immunosorbant assay (DAS-ELISA) test. Market samples of this variety were selected depending on the abundance of visual PRSV symptoms on fruit skin.

Of all the post harvest parameters considered, severe infections significantly decreased the contents of Total soluble solids (TSS) and brightness of the flesh colour ( $\mathrm{L}^{*}$ of $\mathrm{L}^{*} \mathrm{a}^{*} \mathrm{~b}^{*}$ colour space) while other parameters such as titratable acidity (TA), $\mathrm{pH}$, flesh firmness, and $a^{*}, b^{*}$ and hue attributes of flesh colour had negligible effect. However, harvesting at different maturity stages had significant effect on TA, $\mathrm{pH}$ and all the flesh colour attributes 
( $\mathrm{L}^{*}, \mathrm{a}^{*}$ and hue) except $\mathrm{b}^{*}$. Significant interaction between disease severity and harvesting maturity was resulted only for $\mathrm{L}^{*}$ and $\mathrm{b}^{*}$ attributes of flesh colour.

Severe infections in field samples had significantly decreased nutritional parameters such as total amino acids, methionine and tryptophan amino acids and sodium (Na) content. Although percentage ash content, $\beta$ carotene, minerals ( $\mathrm{K}, \mathrm{Mg}, \mathrm{Ca}, \mathrm{Fe}$ and $\mathrm{Zn}$ ), ascorbic acid, crude protein contents, were affected by the infection, the effects were not significant. No significant change in quantities was observed on moisture percentage, crude fat, and the lycopene content between the two disease levels. Market samples with PRSV symptoms recorded significant reduction in lycopene, $\beta$ carotene and $\mathrm{Ca}$ content and a significant increase in amino acid tryptophan with compared to those of fruits with no symptoms. Other nutritional parameters assessed did not exhibit any considerable changes in quantity between the two set of market samples.

Sensory evaluation carried out to determine the effect of PRSV on organoleptic properties such as odour, flavour and overall acceptability revealed that there was no significant effect of the virus infection on organoleptic properties considered. Similar to the field samples, there was no significant effect of virus on the organoleptic properties of market samples due to the virus symptoms.

Non inoculated and inoculated anthracnose lesion development also revealed there was no marked effect on disease development between two disease severity levels as well as between market fruits with and without PRSV symptoms.

In general, PRSV infections negatively affected some of the post harvest parameters and nutritional considerations, while it neither had considerable effect on consumer preference and nor an impact on anthracnose disease development in fruits. 